\title{
Rekayasa Permukaan Lapisan Tipis Kitosan Sebagai Dasar Pengembangan Teknologi Self Cleaning
}

\author{
Eka Rahmawati ${ }^{1{ }^{*}}$, Sry Agustina ${ }^{2)}$ \\ ${ }^{1)}$ Program Pendidikan Fisika, STKIP Bima \\ ${ }^{2)}$ Program Pendidikan Kimia, STKIP Bima \\ Email : ${ }^{1)}$ rahmawatieka89@gmail.com \\ ${ }^{2)}$ sryagustina 92@yahoo.com
}

\begin{abstract}
ABSTRAK : Rekayasa lapisan tipis dari bahan kitosan telah dihasilkan dengan pengaplikasian metode pelapisan dan konsentrasi yang berbeda. Variasi konsentrasi kitosan 0,2\%-1\% serta metode pelapisan spray dan dip coating mengasilkan morfologi yang berbeda yang diamati dengan menggunakan mikroskop optik dengan perbesaran 100 $\mathrm{X}$. Semakin besar konsentrasi maka lapisan yang dihasilkan semakin tidak rata dan kasar. Demikian pula lapisan yang dihasilkan dengan single dip coating akan terlihat lebih rata dan halus bila dibandingkan dengan pelapisan dengan metode multi dip coating dan spray coating. Perbedaan morfologi lapisan dapat dimanfaatkan dalam teknologi self cleaning.
\end{abstract}

Kata kunci: Rekayasa pemukaan, konsentrasi, dip coating, spray coating, morfologi

\section{ABSTRACT}

Modification of the chitosan thin films surface has been produced by using variation chitosan concentration and dip coating and spray coating method. Concentration of chitosan $0.2 \%-1 \%$ and using the different method produce different morphology observed by using a optical microscope with 100X of magnifiction. Increasing of chitosan consentration obtained the uneven and rough surfcce. Meanwhile spray coating produce rougher surface than single and multiple dip coating. The difference of morphology can be used in self cleaning technology.

Key word: surface modification, concentration, dip coating, spray coating, morphology

\section{PENDAHULUAN DAN KAJIAN LITERATUR}

Dewasa ini perkembangan dan pemanfaatan teknologi lapisan tipis semakin meningkat. Dari segi aplikasi secara umum, lapisan tipis telah menjangkau berbagai bidang ilmu. Aplikasi dari teknologi lapisan tipis telah menjangkau dan mengakomodir berbagai bidang, baik bidang fisika, kimia, industri maupun bidang ilmu pengetahuan lainnya. Pada bidang mekanika, teknologi ini banyak digunakan untuk meningkatkan daya tahan korosi. Pada bidang optik, teknologi ini digunakan untuk membuat lensa anti refleksi, cermin reflektor, kaca pelindung cahaya, perlengkapan kamera, pandu gelombang, dan sebagainya. Pada bidang elektronika, lapisan tipis digunakan untuk membuat kapasitor, semikonduktor, head perekam, dan berbagai sensor. Pada bidang industri lapisan tipis digunakan untuk berbagai fungsi dekoratif. Dalam bidang konstruksi terutama yang berkaitan dengan bahan logam, lapisan tipis digunakan sebagai bahan untuk meningkatkan daya tahan korosi.
Pemanfaatan lapisan tipis pada suatu bidang dapat ditentukan dengan sifat fisika maupun kimia dari lapisan yang dihasilkan. Beberapa sifat lapisan tipis yang sering dimanfaatkan adalah sifat bioimobilisasi, listrik, optis, sifat mekanik, tingkat wettability (kebasahan) dan lain sebagainya.

Morfologi lapisan tipis dapat mempengaruhi sifat dan karakteristik lapisan tersebut sehingga dapat digunakan untuk suatu aplikasi tertentu. Beberapa sifat lapisan yang dipengaruhi oleh morfologi lapisan diantaranya adalah wettabilit y (kebasahan), imoblisasi protein, sifat optik, sifat viskoelastik sensor, dan sensing dari suatu sensor. Penelitian yang dilakukan $[1,2,3]$ mengasilkan lapisan tipis polistiren dengan morfologi yang berbeda karena memanfaatkan pelarut yang berbeda untuk meningkatkan imobilisasi protein. Demikian juga yang dilakukan oleh [4] melakukan modifikasi permukaan untuk menghasilkan sifat viskoelastik yang berbeda pada sensor QCM. 
Teknologi Self Cleaning memanfaatkan tingkat wettability lapisan. Dimana nilai wettability dapat memberikan gambaran sifat lapisan yang berupa hidrofobik dan hidrofilik. Lapisan dengan tingkat wettability rendah menggambarkan lapisan yang bersifat hidrofobik dan sebaliknya. Nilai sudut kontak merupakan parameter untuk menyatakan sifat hidrofobik dan hidrofilik lapisan. Lapisan dengan sifat hidrofilik akan melakukan teknologi self cleaning dengan mekanisme fotovoltaik dan bertindak seperti daun lotus jika bersifat hidrofobik.

Untuk memperoleh lapisan dengan kemampuan self cleaning dapat dilakukan dengan beberapa cara diantaranya pemilihan bahan pelapis yang tepat dan melakukan rekayasa permukaan terutama morfologi yang berpengaruh pada tingkat kekasaran lapisan (rouhgness). Salah satu bahan polimer alam yang berpotensi untuk digunakan sebagai lapisan tipis adalah kitosan. Kitosan merupakan turunan dari senyawa kitin yang berasal dari hewan golongan crustaceae seperti udang, lobstrer, dan kepiting. NTB merupakan salah satu daerah yang memiliki potensi perikanan yang sangat besar khususnya kepiting. Selama ini pemanfaatan polimer alami dari bahan kitosan lebih sering digunakan dalam industri farmasi, biokimia, bioteknologi, pengawetan, kosmetik, dan sebagai adsorben logam berat pada limbah industri. Dalam beberapa penelitian, kitosan mampu mengadsorpsi ion logam Ni2+ [5], mengadsorpsi ion $\mathrm{Pb} 2+$ [6]. Kitosan merupakan salah satu polimer alami yang bersifat polikationik yang diperoleh dari deasetilasi kitin dengan struktur [-(1-4)-2-amina-2deoksi-D-glukosa] [7]. Kitosan merupakan bahan polimer alami yang tidak larut dalam air hanya larut dalam asam asetat, biodegradable, reversible, mampu mengikat protein dan lemak. Kitosan mempunyai sifat penting untuk berbagai aplikasi, yaitu kemampuannya mengikat minyak dan air karena terdapat gugus hidrofilik dan hidrofobik. Berdasarkan sifat biologi dan kimianya maka khitosan mempunyai sifat yang khas yaitu mudah dibentuk menjadi spons, larutan gel, pasta, membran, dan serat yang sangat bermanfaat di dalam aplikasinya sebagai edible film yang memperkecil laju barrier oksigen [8].

Dalam penelitian ini akan dilakukan pembuatan dan analisis awal morfologi lapisan tipis kitosan yang diperoleh dengan melakukan beberapa variasi yaitu menggunakan konsentrasi larutan kitosan dan metode pelapisan dip coating/ celup ( satu dan tiga kali celup) dan spray coating. Lapisan kitosan yang terbentuk diamati dengan mikroskop.

\section{METODE PENELITIAN}

Bahan - bahan yang digunakan dalam penelitian ini adalah : Cangkang kepiting, $\mathrm{HCl}$ p.a., $\mathrm{NaOH}$ p.a, $\mathrm{CH} 3 \mathrm{COOH}$ p.a, Ninhidrine, AgNO3, Indikator PP, Aquades, alkohol $75 \%$.

Larutan kitosan dengan variasi konsentrasi $1 \%$, $0,8 \%, 0,6 \%, 0,4 \%$ dan $0,2 \%$ dibuat dengan cara melarutkan bubuk kitosan dalam pelarut asam asetat $\left(\mathrm{CH}_{3} \mathrm{COOH}\right)$. Bubuk kitosan selanjutnya dimasukkan ke dalam gelas beker dan dilarutkan dengan pelarut asam asetat $5 \%$. Untuk mempercepat proses pelarutan, maka campuran kitosan dilarutkan dengan bantuan pemakaian magnetic stirrer agar benar-benar terlarut sempurna. Waktu dibutuhkan agar kitosan benar-benar terlarut adalah $12 \mathrm{jam}$.

Larutan kitosan dengan variasi konsentrasi dari $1 \%, 0,8 \%, 0,6 \%, 0,4 \%$ dan $0,2 \%$ yang telah dibuat, selanjutnya dimasukkan ke dalam lima wadah yang berbeda. Sementara itu, media penumbuhan lapis tipis yaitu kaca preparat dibersihkan permukaannya terlebih dahulu dengan menggunakan alkohol 97\%. Pembuatan lapis tipis dikerjakan dengan dua metode yaitu spray coating (semprot) dan dip coating (celup). Larutan kitosan disemprotkan pada permukaan kaca bberapa kali hingga meuncul lapisan. Sementara pada pembuatan lapisan dengan metode celup, kaca preparat dijepit dengan menggunnakan penjepit dan kemudian dicelupkan ke dalam larutan kitosan dengan konsentrasi yang diinginkan. Proses pencelupan dapat dilakukan maksimal tiga kali perulangan pada kaca preparat yang sama. Kaca preparat yang sudah telapisi kemudian didiamkan pada suhu ruangan hingga kering. Apabila sudah kering, maka preparat harus dimasukkan ke dalam oven dan dipanaskan dengan suhu $100^{\circ} \mathrm{C}$ untuk memastikan tidak ada pelarut yang tersisa pada sampel. Morfologi awal lapisan diamati dengan menggunakan mikroskop optik dengan perbesaran $100 \mathrm{X}$.

\section{HASIL DAN PEMBAHASAN}

Larutan kitosan dibuat dalam lima variasi konsentrasi yang berbeda yaitu yaitu $0,2 \% .0,4 \%, 0,6$ $\%, 0,8 \%$ dan $1 \%(\mathrm{w} / \mathrm{v})$. Variasi konsentrasi tersebut akan mempengaruhi morfologi dan ketebalan lapisan yang dihasilkan. Berdasarkan pengamatan awal dengan menggunakan mikroskop optik, maka diperoeh tampilan lapis tipis kitosan di atas substrat kaca sebagai berikut : 
Konsentrasi $1 \%$

Konsentrasi 0,8 \%

Konsentrasi 0,6\%

Konsentrasi 0,4 \%

Konsentrasi 0,2\%
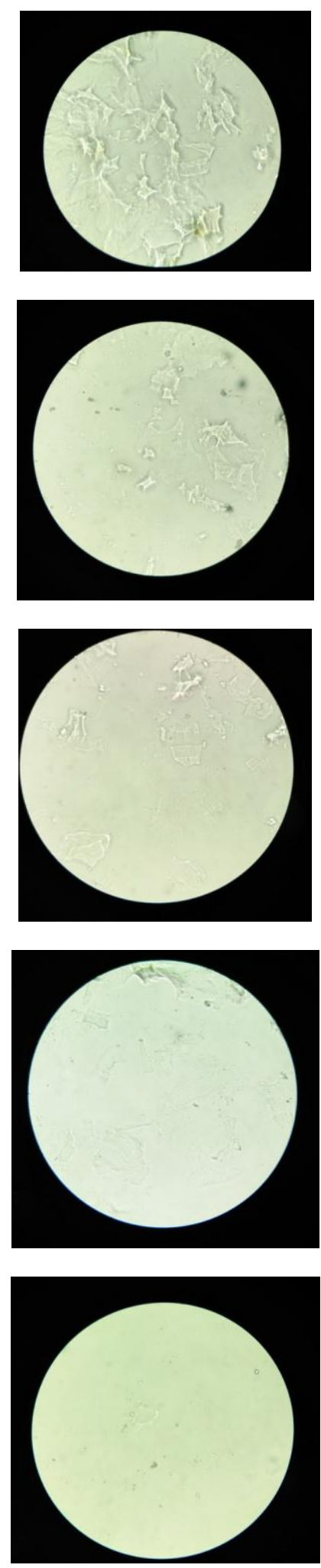

Gambar 1: Morfologi lapisan kitosan diamati dengan mikroskop optik perbesaran $100 \mathrm{X}$, a) konsentrasi $1 \%$, b) konsentrasi $0,8 \%$, c) konsentrasi $0,6 \%$,d) konsentrasi $0,4 \%$, e) konsentrasi $0,2 \%$

Dari beberapa gambar di atas dapat dilihat bahwa, perbedaan konsentrasi larutan kitosan akan dapat mempengaruhi morfologi lapis tipis kitosan yang dihasilkan. Pada konsentrasi kitosan yang paling tinggi (1\%), tampak bahwa lapisan kitosan yang dihasilkan sangat kasar dan tebal dengan penyebaran yang kurang merata. Sementara pada konsentrasi yang semakin kecil menghasilkan lapisan yang mulai terlihat halus dan merata dengan ketebalan yang semakin berkurang. Berdasarkan penggunaan variasi konsentrasi kitosan yang telah dilakukan, kitosan dengan konsentrasi 0,4 $\%$ menghasilkan lapisan dengan permukaan yang terlihat halus dan merata. Sementara lapisan kitosan $0,2 \%$ menghasilkan lapisan yang sangat tipis. Sehingga pada proses selanjutnya lapisan kitosan yang diperoleh dari larutan kitosan 0,4\% digunakan untuk variasi pembuatan lapisan kitosan. Semakin besar konsentrasi larutan yang digunkan, maka lapisan yang terbentuk semakin tebal. Hal ini disebabkan karena setelah proses coating selesai, maka sejumlah pelarut akan menguap. Hal ini menyebabkan peningkatan konsentrasi biopolimer secara cepat yang menyebabkan peningkatan viskositas. Setelah terjadinya penguapan pelarut, lapisan biopolimer uniform akan terbentuk. Akan tetapi, lapisan polimer yang baru terbentuk masih dalam keadaan belum stabil dan masih terdapat sisa pelarut. Menghilangnya sebagian besar pelarut menyebabkan pergerakan rantai terhambat. Pelarut yang tersisa tersebut akan dapat mempengaruhi pergerakan rantai dan kehomogenan. Penguapan pelarut tergantung pada transfer massa dari cair ke fase gas dan kondisi aliran fluida dalam fase gas.

Pembentukkan suatu lapis tipis dapat dilakukan dengan berbagai cara seperti metode celup (dip coating), metode semprot (spray coating), metode kimia, metode evaporasi dan lain sebagainya. Dalam penelitian ini, lapis tipis kitosan terbentuk dengan menggunakan metode celup (mono dan multi coating) dan metode semprot. Berikut ini merupakan tampilan lapis tipis kitosan di atas substrat kaca yang diperoleh dari pengamatan menggunakan mikroskop optik

$\begin{array}{lll}\text { a } & b & c\end{array}$

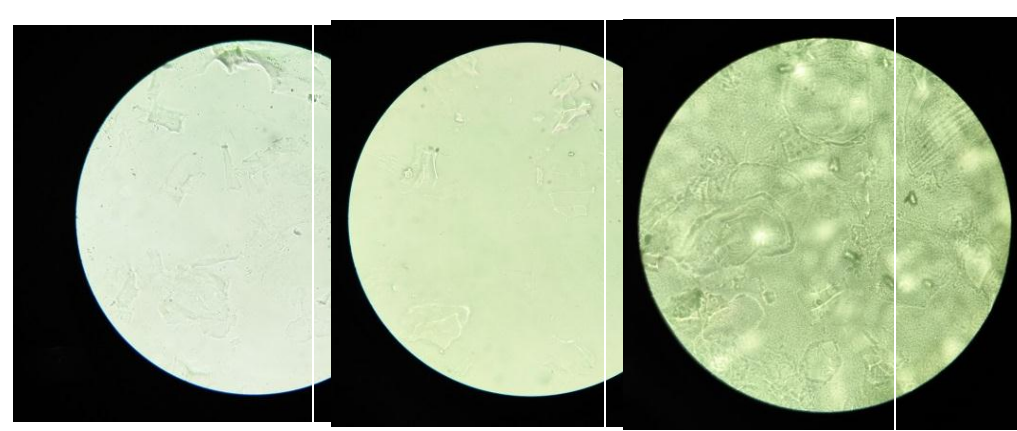

Gambar 2: Morfologi lapisan kitosan dengan menggunakan mikroskop optik perbesaran $100 \mathrm{X}$ a) metode celup single coating, b) metode celup multi coating, c) metode spray coating 
Berdasarkan gambar 5.4 di atas terlihat bahwa lapisan tipis kitosan yang diperoleh dengan metode celup single coating dan multi coating lebih merata dibandingkan dengan metode spray coating. Namun demikian, lapisan yang dihasilkan dengan metode spray coating terlihat lebih tipis. Pelapisan kitosan dengan metode dip coating (celup) membuat lapisan lebih rata jika dibandingkan dengan mengguanakan metode semprot [9]. Morfologi lapisan yang dihasilkan berbeda untuk masing-masing konsentrasi dan metode pelapisan yang digunakan. Untuk dapat mengetahui pengaplikasan kitosan dalam teknologi self cleaning, maka perlu dilakukan karakterisasi wettability lapisan lebih lanjut. Keaksaran yang berbeda akan menghasilkan tingkat wettability yan berbeda.

\section{KESIMPULAN}

Lapisan tipis kitosan yang dibuat dengan metode celup dan semprot serta variasi konsentrasi memberikan penampakan morfologi lapisan yang berbeda. Semakin besar konsentrasi larutan kitosan, maka semakin kasar lapisan yang dihasilkan. Sementara pelapisan dengan metode semprot menghasilkan lapisan yang tidak merata dibandingkan dengan pelapisan metode celup. Tingkat kekasaran dan morfologi yang lapisan dapat ditinjau lebih jauh dengan menggunakan SEM dan alat pengukuran kekasaran lainya.

\section{DAFTAR PUSTAKA}

[1] Djoko, D. J. D. H., Didik, L. A., Rahmawati, E., Pagaga, M., \& Sakti, S. P. (2014). Solvent effect on morphology of polystyrene coating and their role to improvement for biomolecule Immobilization in application of QCM based biosensor. In Applied Mechanics and Materials (Vol. 530, pp. 54-57). Trans Tech Publications.

[2] SAKTI, Setyawan P.; RAHMAWATI, Eka; ROBIANDI, Fadli. Solvent effect on polystyrene surface roughness on top of QCM sensor. In: AIP Conference Proceedings. AIP Publishing, 2016. p. 030017.

[3] RAHMAWATI, Eka, et al. Effect of Xylene and Tetrahydrofuran Solvent Type on Polystyrene Layer Thickness With Spin Coating Method. Natural B, 2014, 2.4: 349-354.

[4] Rahayu, S., Masruroh, M., Santjojo, D. H., Rahmawati, E., Didik, L. A., Robiandi, F., \& Sakti, S. P. (2014). Effects of Polystyrene Solvent Difference on Morphology of
Polystyrene Layers and Viscoelastic Properties of QCM Biosensors. Natural B, 2(4), 343-348.

[5] Rochima, E., Suhartono, M. T., Syah, D., dan Sugiyono. 2004. Karakterisasi Kitosan Hasil Deasetilasi Enzimatis oleh Kitin Deasetilase Isolat Bacillus papandayan K29-14. Universitas Padjajaran.

[6] Sanjaya, I., dan Yuanita, L. 2007. Adsorpsi Pb(II) oleh Kitosan Hasil Isolasi Kitin Cangkang Kepiting Bakau (Scylla). J Ilmu Dasar 8(1): 30-36.

[7] Puspawati, N.M, dan N. Simpen. 2010. Optimasi Deasetilasi Khitin dari Kulit Udang dan Cangkang Kepiting Limbah Restoran Seafood Menjadi Kitosan Melalui Variasi Konsentrasi $\mathrm{NaOH}$. Jurnal Kimia, 4 vol (1): 79-90.

[8] Supeni, guntarti; irawan, suryo. 2012. Pengaruh Penggunaan Kitosan Terhadap Sifat Barrier Edible Film Tapioka Termodifikasi. Balai Besar Kimia dan Kemasan, Kementerian Perindustrian RI. Jakarta Timur

[9] Previta, A; Dahlan, A. 2013. Sintesis Lapisan TiO2 Menggunakan Prekursor $\mathrm{TiCl}_{4}$ Untuk Aplikasi Kca Self Cleaning dan Anti Fogging. Jurnal Fisika. Fakultas Matematika dan Ilmu Pengetahuan Alam Universitas Andalas 